\title{
PENDIDIKAN KESEHATAN TENTANG COVID-19 BAGI KELOMPOK KHUSUS
}

\author{
Lucia Andi Chrismilasari $^{* 1}$, Luckyta Ibna Permana ${ }^{2}$, \\ Fransiska Dwi Hapsari ${ }^{3}$ \\ ${ }^{1,2,3}$ Program Studi Ilmu Keperawatan, STIKES Suaka Insan Banjarmasin \\ *luciachrismilasari@gmail.com
}

\begin{abstract}
ABSTRAK
Corona Virus Disease-2019 (COVID-19) di Indonesia terus mengalami peningkatan. Semua kelompok masyarakat perlu saling membantu dalam menekan angka penyebaran COVID-19. Akan tetapi, tidak semua masyarakat mendapakan informasi secara tepat tentang COVID-19, misalnya pada kelompok masyarakat khusus seperti penyintas tunarungu. Maka dari itu, pendidikan kesehatan kepada kelompok masyarakat khusus seperti penyintas tunarungu perlu dilakukan tanpa harus mengumpulkan mereka pada 1 tempat dan waktu yang sama, yaitu dengan video edukasi tentang COVID-19 yang menampilkan bahasa isyarat sebagai cara penyampaian informasinya. Dari hasil kegiatan didapatkan hasil yaitu 1)tersampaikanya informasi tentang COVID-19 bagi masyarakat khusus penyintas tunarungu; dan 2)tersedianya video edukasi yang berisi informasi tentang COVID-19 dengan menggunakan bahasa isyarat. Video edukasi ini sangat bermanfaat bagi kelompok masyarakat khusus penyintas tunarungu untuk memahami tentang COVID-19 dan cara penularannya. Selain itu juga, video edukasi ini dapat disebarluaskan kepada seluruh masyarakat melalui media sosial guna menyebarluaskan informasi terkhusus bagi penyintas tunarungu di seluruh Indonesia. Sehingga, dapat membantu agar semua kelompok masyarakat medapatkan informasi tentang COVID-19 dan cara pencegahannya.
\end{abstract}

Kata Kunci: Diabetes Melitus, Kader Kesehatan, Pelatihan

A . PENDAHULUAN

Saat ini dunia tengah menghadapi masalah pandemi virus yang dikenal dengan Corona Virus Disease-2019 (COVID-19). Sebanyak 218 negara di dunia melaporkan kejadiannya (WHO, 2020). Salah satu negara yang tidak luput dari penularan COVID-19 adalah
Indonesia sendiri. Pada tanggal 2 maret 2020, Indonesia melaporkan kasus pertama sebanyak 2 kasus. Tanggal 25 Maret 2020 meningkat menjadi 790 kasus yang tersebar di 24 provinsi di Indonesia. Tanggal 10 oktober 2020, kasus terkonfimasi positif di Indonesia meningkat hingga mencapai 328.952 jiwa, 
dengan 251.481 jiwa dinyatakan sembuh, dan 11.765 jiwa meninggal dunia (covid-19, 2020).

Dampak akibat pandemi ini juga sangat mempengaruhi kehidupan manusia. Mulai dari dampak kesehatan, dampak sosial dan ekonomi secara global (Syafrida \& Hartati, 2020). Untuk menekan dampak akibat pandemi COVID-19, seluruh negara termasuk Indonesia melakukan berbagai cara guna menekan angka penyebaran virus dikalangan masyarakat. Penerapan Pembatasan Sosial Berskala Besar (PSBB), menutup sementara akses masuk dari luar negara menuju Indonesia dan edukasi terkait New Normal. Semua kegiatan dilakukan guna menekan angka kasus positif COVID-19.

\section{Edukasi tentang COVID-19} dan kegiatan New Normal digalakan oleh pemerintah pusat dan daerah. Edukasi ini ditujukan untuk meningkatkan pengetahuan dan menyadarkan perilaku masyarakat dalam upaya mengenal dan mencegah penyebaran COVID-19. Sudah banyak media yang melaksanakan edukasi COVID-19, namun masih belum ada bentuk edukasi yang bisa dipahami oleh beberapa kelompok khusus masyarakat seperti kelompok tunarungu. Berdasarkan masalah tersebut maka solusi yang ditawarkan adalah menyiapkan media edukasi berisi informasi terkait COVID19 yang dapat dipahami juga oleh kelompok khusus masyarakat penyintas tunarungu.

\section{B. METODE}

Upaya dalam meningkatkan pengetahuan sehingga berdampak perubahan perilaku kelompok khusus seperti penyintas tunarungu terkait pencegahan COVID-19 diperlukan saat ini. Salah satunya dengan kegiatan promosi kesehatan. Promosi kesehatan merupakan suatu program perubahan perilaku masyarakat yang menyeluruh dalam konteks masyarakat (Notoatmodjo., 2005). 
Akan tetapi, di era digitalisasi dan kondisi pandemi COVID-19 saat ini, promosi kesehatan lebih ditekankan pada penggunaan media elektronik dan media sosial. Tujuannya menyampaikan informasi tanpa menimbulkan kerumunan massa. Sehingga, informasi tetap tersampaikan. Maka dari itu, kegiatan pengabdian dilaksanakan dengan metode penyuluhan, menggunakan media Audio Visual atau rekaman video tentang COVID-19. Dimana, pada video menampilkan edukasi dengan bahasa isyarat, sehingga video ini dapat dipahami oleh kelompok khusus terutama bagi penyintas tunarungu.

Video ini disebarluaskan kepada penyintas tunarungu melalui Aplikasi Whatsapp Masangger, media sosial seperti Instagram, Facebook dan YouTube. Tujuannya agar informasi ini dapat tersebarluaskan dan tersampaikan kepada penyintas tunarungu di berbagai wilayah di Kalimantan Selatan bahkan seluruh Indonesia. Peran media dalam memberikan informasi, pengetahuan kepada masyarakat berkaitan perkembangan wabah COVID-19 dapat membantu memutus rantai penyebaran virus COVID-19 (Syafrida \& Hartati, 2020). Selain itu juga, himbauan terkait social distancing perlu digalakan di media sosial guna meningkatkan pengetahuan dan kesadaran pentingnya cara penyebaran COVID-19 di masyarakat (Karyono, Rohadin, \& Indriyani, 2020).

\section{Hasil dan Pembahasan}

Secara umum, kegiatan pengabdian ini menghasilkan 1 buah video edukasi yang berisi informasi tentang COVID-19 seperti: tanda dan gejala COVID19, cara pencegahan dan penyebaran COVID-19 serta cara cuci tangan yang benar. Video edukasi ini bertujuan untuk menyampaikan informasi yang benar tentang COVID-19. Sehingga pengetahuan masyarakat tentang COVID-19 dapat semakin meningkat. Sugiyono (2005) menguraikan bahwa kegiatan 
promosi kesehatan dengan pendidikan/edukasi merupakan upaya persuasi atau pembelajaran kepada masyarakat agar masyarakat mau melakukan tindakan-tindakan (secara praktik) untuk memelihara (mengatasi masalah) dan meningkatkan kesehatannya. Salah satu pendidikan kesehatan melalui metode video. Pendidikan kesehatan melalui video ternyata berdampak positif dalam meningkatkan pengetahuan penerima informasi (Prasko, Sutomo, \& Santoso, 2016). Walaupun dampak yang ditimbulkan tidak jauh berbeda apabila melaksanakan pendidikan kesehatan dengan metode lain (Adha, Wulandari, \& Himawan, 2016). Akan tetapi, dimasa pandemi COVID-19 saat ini pendidikan kesehatan kepada masyarakat lebih baik dilaksanakan tanpa harus mengumpulkan massa. Sehingga video edukasi menjadi salah satu alternatif yang efektif digunakan untuk penyampaian informasi kepada masyarakat luas.
Kegiatan pengabdian masyarakat ini juga menghasilkan 1 video edukasi tentang COVID19 yang dapat dimanfaatkan bagi penyintas Tunarungu. Dalam video menampilkan seseorang yang menyampaikan informasi tentang COVID-19 menggunakan bahasa isyarat. Somantri (2007) mengemukakan bahwa tunarungu dapat diartikan sebagai suatu keadaan seseorang yang mengalami kehilangan pendengaran. Seseorang dengan tunarungu memiliki keterbatasan dalam menerima informasi edukasi. Menurut Notoadmodjo (2010) informasi didapat dari pancaindera, utamanya adalah indera penglihatan dan pendengaran untuk membentuk pengetahuan. Akan tetapi, dengan keterbatasan pada penyintas tunarungu, maka informasi disampaikan dengan cara yang berbeda yaitu melalui bahasa isyarat. Bahasa isyarat merupakan salah satu komunikasi non verbal yang pada proses komunikasinya tetapi tidak menggunakan bahasa atau kata-kata. Ling (1989) 
mengemukakan bahwa bahasa isyarat merupakan kaidah berkomunikasi yang digunakan oleh golongan bermasalah pendengaran (Fauzan \& Ruthnia).

Tersedianya dan tersampaikannya informasi terkait COVID-19 meliputi cara pencegahan dan penyebaran COVID-19 serta cara cuci tangan yang benar, sangat bermanfaat bagi kelompok masyarakat khusus yaitu penyintas tunarungu. Orang dengan keterbatasan (pendengaran) juga akan mendapatkan informasi tentang COVID-19. Sehingga kelompok khusus seperti penyintas tunarungu juga memiliki pengetahuan terutama terkait cara menekan penularan COVID-19 dilingkungan masyarakat. Harapannya pengetahuan ini dapat menjadi dasar dalam merubah perilaku para penyintas tunarungu untuk menjalani kegiatan seharihari dengan normal tetapi tetap menjaga protokol kesehatan. Notoatmodjo

mengemukakan bahwa pengetahuan merupakan komponen dasar dalam sebuah perilaku. Perilaku seseorang untuk lebih disiplin mematuhi aturan, kebijakan dan himbauan sangat diperlukan guna memutus mata rantai penyebaran COVID-19 (Syafrida \& Hartati, 2020).

\section{Kesimpulan}

Seluruh elemen masyarakat sangat diperlukan keterlibatannya dalam mengendalikan penyebaran COVID-19 di tanah air. Kesadaran untuk menjalani kebiasan baru selama masa pandemi perlu ditingkatkan lagi terutama dalam berperilaku. Karena, masih banyak kelompok masyarakat yang belum menyadari akan pentingnya dan cara yang tepat dalam menjalani kegiatan sehari-hari tetapi tetap memperhatikan protokol kesehatan. Maka dari itu, upaya meningkatkan pengetahuan masyarakat tentang COVID-19 terutama cara pencegahannya perlu digencarkan dengan memberikan pendidikan kesehatan yang dapat diakses oleh masyarakat tanpa harus mengumpulkan massa. Salah 
satunya adalah dengan video

edukasi.

Video edukasi juga sangat berguna bagi penyintas tunarungu. Terutama video yang dikhususkan bagi mereka yang mampu berkomunikasi dengan bahasa isyarat. Sehingga informasi terkait cara pencegahan COVID-19 juga tersampaikan kepada kelompok

\section{DAFTAR PUSTAKA}

Adha, A. Y., Wulandari, D. R., \& Himawan, A. B. (2016). Perbedaan Efektivitas Pemberian Penyuluhan Dengan Video dan Simulasi Terhadap Tingkat Pengetahuan Pencegehan TB Paru. Jurnal Kedokteran Diponegoro, 5(4), 565-579.

covid-19, S. t. (2020). peta sebaran. satuan tugas penanganan covid-19.

Fauzan, \& Ruthnia, F. (n.d.). Aktifitas Sosialisasi Bahsa Isyarat Indonesia di Organisasi Gerkatin Solo. jurnal kommas. Retrieved from http://www.jurnalkommas.co m/docs/JURNAL\%20D02110 41.pdf masyarakat khusus. Video edukasi juga dapat disebarluaskan melalui media sosial dan media telekomunikasi atau media elektronik lainnya. Sehingga, penyampaian informasi bagi yang memerlukan (khusus penyintas tunarungu) dapat tersebar secara luas.

Karyono, Rohadin, \& Indriyani, D. (2020). Penanganan dan Pencegahan Pandemi Wabah Virus Corona (COVID-19) kabupaten Indramayu. Jurnal Kolaborasi Resolusi Konflik, 164-173.

Prasko, Sutomo, B., \& Santoso, B. (2016). Penyuluhan Metode Audio Visual dan Demonstrasi Terhadap Pengetahuan Menyikat Gigi pada Anak Sekolah Dasar. Jurnal Kesehatan Gigi, 3(2), 53-57.

Syafrida, \& Hartati, R. (2020). Bersama Melawan Virus Covid-19 di Indonesia. SALAM (Jurnal Sosial \& Budaya Syar-i, 495-508. doi:10.15408/sjsbs.v7i6.1532 5

WHO. (2020). WHO Coronavirus Disease (COVID-19) Dashboard. WHO. 